La Revista Panamericana de Salud Pública/Pan American Journal of Public Health se complace en publicar cartas de los lectores dirigidas a estimular el diálogo sobre los diversos aspectos de la salud pública en las Américas, así como a esclarecer, discutir o comentar de manera constructiva las ideas expuestas en la revista. Las cartas deben estar firmadas por el autor y especificar su afiliación profesional y dirección postal. Cuando se trate de comentarios sobre un artículo que requieren contestación del autor, se procurará conseguir esa respuesta con el fin de publicar ambas cartas. La Redacción se reserva el derecho de editar las cartas recibidas y resumirlas para mejorar su claridad.

The Revista Panamericana de Salud Pública/Pan American Journal of Public Health publishes letters from readers for the purpose of stimulating dialogue on various aspects of public health in the Americas and of constructively clarifying, discussing, and critiquing the ideas expressed throughout its pages. Letters should be signed by the author and include his or her professional affiliation and mailing address. If a commentary on a given article requires a reply from the author, an effort will be made to obtain the reply and to publish both letters. The editorial team reserves the right to edit all letters received and to condense them so as to improve their clarity.

\section{RUBELLA AND CONGENITAL RUBELLA SYNDROME IN THE AMERICAS}

Désinor et al. (1) reported serologic data on the rubella virus immunoglobulin $\mathrm{G}(\mathrm{IgG})$ antibody status of 495 pregnant women reporting at the Obstetrics and Gynecology Department of the State University Hospital in the city of Port-au-Prince, Haiti. Those researchers mentioned that they had decided to study the problem of rubella and congenital rubella syndrome (CRS) in Haiti because of a confirmed case of CRS at the State University Hospital.

When they are managing CRS cases, susceptible health care workers have a risk of acquiring and subsequently transmitting the potentially teratogenic rubella infection to their patients. Although rubella susceptibility status among health personnel has been periodically evaluated in hospitals around the world, males have often received inadequate attention in both antibody prevalence investigations and the vaccination of susceptible persons.

Consider the case of Australia, as reported in research carried out by Kelly et al. (2). Before rubella vaccine was introduced in the country in 1970, rubella was mainly a disease of children of primary school age. Vaccination programs changed both rubella age and sex susceptibility. Between
July 2001 and June 2002, 29 of the 32 laboratoryconfirmed cases of rubella ascertained from enhanced surveillance in the state of Victoria were males aged $20-42$ years. When rubella IgG concentrations were determined for 934 residual diagnostic sera stored at the Victorian Infectious Diseases Reference Laboratory, among all subjects aged 1-55 years, males were more susceptible to rubella infection than were females $(10.2 \%$ vs. $2.6 \%, P<0.0001)$. Australia's past rubella immunization policies have resulted in a susceptible cohort of adult males, and a rubella vaccination program targeting men 17-44 years old should be considered, those investigators concluded.

A rubella IgG serosurvey was conducted recently among 1000 female employees at three ophthalmic hospitals in the state of Tamil Nadu, India (3). The survey found that $15.0 \%$ of the women were seronegative. Susceptibility increased with age, from $13.0 \%$ in those aged $18-19$ years old to $23.9 \%$ in those $30-40$ years old. Among 89 medical residents in a pediatric hospital in Mexico City who were screened for rubella antibody, 58 were females (4). Of those 89 residents, 12 of them (10 women and 2 men) were seronegative.

In 2003 the Directing Council of the Pan American Health Organization passed a resolution calling for the elimination of rubella and CRS from 
the Americas by the year 2010 (5). As that resolution is implemented, it is obvious that male staff employed in health care establishments should not be ignored during any screening for rubellasusceptible persons. Immunizing both males and females who are rubella-susceptible would be costeffective. Clearly there is a need to screen and immunize all susceptible males who work in hospitals and thus prevent those individuals from amplifying and propagating rubella virus in the health facilities.

\section{REFERENCES}

1. Désinor OY, Ansèlme RJP, Laender F, Saint-Louis C, Bien-Aime JE. Seroprevalence of antibodies against rubella in pregnant women. Rev Panam Salud Publica. 2004;15(3):147-50.

2. Kelly H, Worth L, Karapanagiotidis T, Riddell M. Interruption of rubella virus transmission in Australia may require vaccination of adult males: evidence from a Victorian sero-survey. Commun Dis Intell. 2004;28:69-73.

3. Vijayalakshmi P, Anuradha R, Prakash K, Narendran K, Ravindran M, Prajna L, et al. Rubella serosurveys at three Aravind eye hospitals in Tamil Nadu, India. Bull World Health Organ. 2004;82:259-64.

4. Villasís-Keever MA, Peña LA, Miranda-Novales G, Alvarez y Muñoz T, Damasio-Santana L, López-Fuentes G, et al. Prevalence of serological markers against measles, rubella, varicella, hepatitis $B$, hepatitis $C$, and human immunodeficiency virus among medical residents in Mexico. Prev Med. 2001;32:424-8.

5. Andrus JK, Roses Periago M. Elimination of rubella and congenital rubella syndrome in the Americas: another opportunity to address inequities in health. Rev Panam Salud Publica. 2004;
E-mail: subhshji@hotmail.com
15(3):145-6.

Subhash C. Arya

Nirmala Agarwal

Sant Parmanand Hospital

18 Alipore Road

Delhi- 110054, India

\section{Observatorio de Políticas Públicas y Salud}

El Observatorio de Políticas Públicas y Salud (OPPS) es un proyecto creado en el año 2000 para fomentar la investigación, formar profesionales y brindar asesoramiento en el ámbito de las políticas públicas y la salud. Participan en él la Universidad de Alicante (España), la Universidad de Antioquia (Colombia), la Universidad del Atlántico (Colombia), la Universidad de El Salvador (El Salvador) y la Facultad de Ciencias Médicas de Porto Alegre (Brazil). El proyecto cuenta, además, con el apoyo de la Organización Panamericana de la Salud y de otros organismos internacionales.

En general los objetivos del OPPS son: 1) generar conocimientos útiles para el análisis de las políticas que inciden sobre la salud por medio de la investigación; 2) formar investigadores y profesionales vinculados a universidades y agencias de salud pública en América Latina y España; 3) difundir los nuevos conocimientos generados por las investigaciones entre las agencias, instituciones y comunidades de ambas regiones; 4) formular propuestas y recomendaciones de políticas que contribuyan a mejorar la salud en España y América Latina, y 6) fomentar y evaluar el desarrollo de tecnologías que faciliten la investigación y la gestión de políticas públicas relacionadas con la salud.

La formación de personal se lleva a cabo principalmente mediante cursos, seminarios y becas para la investigación. El proyecto cuenta con su propia página web, donde se proporciona información más detallada para los interesados. La página se encuentra en la siguiente dirección: http://www.ua.es/dsp/observatorio/opps.htm 